\title{
PENERAPAN PEMBELAJARAN BACA TULIS AL-QUR'AN DENGAN MENGGUNAKAN METODE AL-HUSNA DI SD NEGERI CANDIREJO
}

\author{
Mustaidah, Bekti Taufiq Ari Nugroho \\ SD Negeri Candirejo, IAIN Salatiga \\ musta’idahkintelan@gmail.com, bektitaufiq65@gmail.com
}

This type of research is descriptive qualitative, namely qualitative research that seeks to describe and interpret objects in accordance with what they are. This method is used to analyze data regarding the object of research, namely SD Negeri Candirejo, and to conclude data in the field related to the implementation of the Al-Husna method in learning to read the Al-Qur'an.

The results of his research are the application of the Al-Husna method in SD Negeri Candirejo, which has its own characteristics, namely the Classical and Individual approaches. The Al-Husna method approach is carried out with 3 techniques, namely: 1) Technique 1 (tartil namely Tartil is mentajwidi letter and recognizing where to waqaf); 2) Technique 2 (the teacher reads the students imitates); 3) Technique 3 teachers and students both read using the rules of Rasm Utsmani. Evaluation in this tilawati is carried out every 3 months to increase the volume. As for the increase in pages at the end of the meeting before returning home, with provisions from the educator, and in accordance with the guidelines for implementing the order. Keywords: Read and write Al-Qur'an, Al-Husna Method

\section{Abstrak}

Jenis penelitian ini adalah kualitatif deskriptif, yaitu penelitiankualitatif yang berusaha menggambarkan dan menginterpretasi objek sesuai dengan apa adanya. Metode ini digunakan untuk menganalisis data mengenai obyek penelitian yaitu SD Negeri Candirejo, serta untuk menyimpulkan data-data di lapangan yang berhubungan dengan pelaksanaan metode Al-Husna dalam pembelajaran membaca Al-Qur`an.

Hasil penelitiannya adalah Penerapan metode Al-Husna di SD Negeri Candirejo, mempunyai ciri khas tersendiri yaitu dengan pendekatan Klasikal dan Individual. Pendekatan metode Al-Husna dilaksanakan dengan 3 tehnik yaitu: 1) Tehnik 1 (tartil yaitu Tartil ialah mentajwidi huruf dan mengenal dimana harus waqaf); 2) Tehnik 2 (guru membaca siswa menirukan); 3) Tehnik 3 guru dan siswa sama-sama membaca dengan kaidah rasm utsmani. Evaluasi dalam tilawati ini dilakukan setiap 3 bulan sekali untuk kenaikan jilid. Sedangkan untuk kenaikan halaman setiap di akhir pertemuan sebelim pulang, dengan ketentuan dari pendidik, dan sesuai pedoman pelaksanaan imtihan.

Kata Kunci: Baca Tulis Al-Qur'an, Metode Al-Husna 


\section{A. Latar Belakang Masalah}

Pendidikan dilakukan agar seseorang memperoleh pemahaman tentang suatu ilmu. Pendidikan juga mempermudah seseorang menyesuaikan diri dengan lingkungan sekitar. Dalam pelaksanaannya pendidikan bermula dari seorang pendidik yang mampu menjadikan suasana pendidikan komunikatif dan menyenangkan.sehingga proses pembelajaranpun dapat berjalan dengan lancar dan dapat hasil yang memuaskan. Al-Qur`an adalah kalamullah sebagai pedoman hidup manusia. Untuk dapat memahami ajarannya yaitu dengan cara dibaca, ditulis, dihafalkan, dipahami maknanya, dan dilaksanakan isinya.

Al-Qur`an diberi pengertian sebagai kalam Allah SWT yang diturunkan atau diwahyukan kepada Nabi Muhammad melalui perantara Malaikat Jibril, yang merupakan mukjizat, yang diriwayatkan secara mutawatir yang ditulis di mushaf dan membacanya dinilai ibadah. ${ }^{1}$ Dalam surat Al-Isra` ayat 106 telah diterangkan proses turunnya Al-Qur`an.

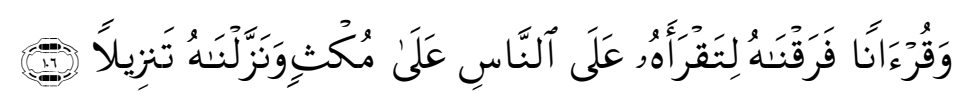

Artinya: "Dan Al Quran itu Telah kami turunkan dengan berangsurangsur agar kamu membacakannya perlahan-lahan kepada manusia dan kami menurunkannya bagian demi bagian".

Allah datangkan kepada manusia Al-Qur`an, yang Allah pisahpisahkan, yakni Allah menurunkan Al-Qur`an itu secara terpisahpisah dan berangsur-angsur pada malam lailatul Qadar di bulan Ramadhan selama 23 tahun, Sesuai dengan kejadian-kejadian yang berkaitan dengan turunnya masing-masing ayat.

Adapun maksud diturunkannya Al-Qur’an secara berangsur-angsur, bagia demi bagian adalah agar nabi Muhammad bisa membaca dan

${ }^{1}$ Ahmad Syarifuddin, Mendidik Anak Membaca, Menulis, Dan Mencintai Al-Qur`An, (Jakarta, Gema Insani, 2005), cet.11, hlm.15. 
mengajarkannya pada umat manusia dengan perlahan dan hati-hati sehingga mudah untuk menghayatinya. Dengan demikian lebih membantu pemahaman maknanya. ${ }^{2}$

Mempelajari Al-Qur'an bagi setiap umat Islam merupakan suatu kewajiban. Langkah pertama untuk mempelajari Al-Qur'an adalah belajar membaca. Karena seseorang yang dapat membaca tulisan maka langkah selanjutnya seseorang dapat menulis, dan dengan membaca orang hafal dengan abjad huruf-huruf dasar. Membaca Al-Qur'an tidak lepas dari istilah Murotal (membaca dengan irama atau lagu). Karena menyangkut dengan kecintaan dan penjiwaan bagi orang yang mentadabur $\mathrm{Al}$-Qur`an dan juga merupakan sunnah Nabi, sebagaimana sabda beliau:

Artinya: "Hadis dari Utsman bin Abi Syaibah, hadis dari Jarir dari 'Amsy, dari Thalhah, dari Abdur Rohman bin 'Ausyajah, dari Barai bin 'Azib berkata, Rasulullah SAW bersabda: "Hiasilah Al-Qur'an kalian dengan suara kalian." (HR. Abu Dawud).

Pada saat sekarang ini masih banyak metode membaca Al-Qur`an yang cenderung konvensional, yaitu dengan nada lurus sehingga terkesan monoton yang berdampak pembelajaran kurang dapat diminati oleh siswa sehingga berdampak pada hasil belajar siswa. Mempelajari Al-Qur`an termasuk cara membacanya dengan baik dan benar tidaklah mudah seperti halnya membalik tangan. Selain harus mengenal huru-huruf hijaiyah tentu juga dibutuhkan keterampilan sendiri agar dapat membaca Al-Qur`an secara tartil. Tartil artinya membaca Al-Qur`an dengan perlahan lahan dan tidak terburu-buru dengan bacaan baik dan benar sesuai dengan makhraj dan sifat-sifatnya sebagaimana di jelaskan dalam ilmu tajwid. ${ }^{3}$

${ }^{2}$ Ahmad Musthafa Al-Maraghi, Tafsir Al-Maraghi ,juz XV, (Semarang: Karya Thoha Putra, 1993), hlm.213.

${ }^{3}$ Abdul Majid Khon, Praktikum Qiraat Keanehan Bacaan Al-Qur`An Qiraat Ashim Dari Hafash, (Jakarta: sinar grafika offset, 2008), cet.1, hlm.44 
Dari kata tartil inilah lahir istilah murotal yaitu pembacaan Al-Qur`an secara baik, benar dan lancar dengan irama standar.

Dasar membaca dalam Al-Qur'an sudah diterangkan bahwasannya membaca adalah langkah untuk memahami sesuatu.

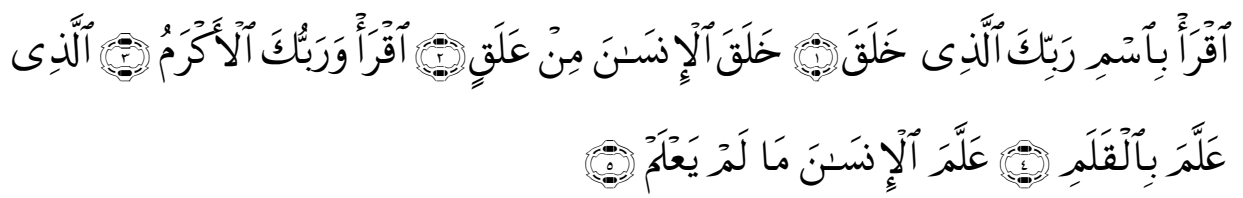

Artinya: "Bacalah dengan (menyebut) nama Tuhanmu yang Menciptakan. Dia Telah menciptakan manusia dari segumpal darah. Dan Tuhanmulah yang Maha pemurah, Yang mengajar (manusia) dengan perantaran kalam. Dia mengajar kepada manusia apa yang tidak diketahuinya".

Ayat di atas megungkapkan bahwasannya membaca adalah suatu langkah awal di mana seseorang mendapat ilmu pengetahuan dari pembacaan kemudian timbullah pemahaman sehingga terciptalah suatu ilmu pengetahuan. Belajar adalah salah satu upaya membentuk peradaban yang dicita-citakan oleh masyarakat muslim, maka pemahaman terhadap Al-Qur`an harus ditingkatkan agar tidak terjadi kesalahan dalam menangkap pesan yang terkandung di dalamnya.

Sebutan bacaan yang baik memiliki banyak aspek, selain etika dalam membaca Al-Qur`an, kata baik juga menyangkut sikap terhadap AlQur`an. Dalam membaca Al-Qur`an seorang muslim taksekedar memenuhi persyaratan seperti suci badan, pakaian dan tempat, akan tetapi juga menyucikan hati dan perasaan, agar saat membaca Al-Qur’an yang muncul di hati adalah perasaan cinta dan penuh kerinduan kepada sang pemilik Al- Qur`an.

Pada dasarnya Al-Qur`an itu mudah dipelajari, tidak susah dan tidak berat, dengan syarat ada kemauan, keseriusan dan kesungguhan dalam mempelajarinya. Hal tersebut ditegaskan dalam surat Al-Qamar Ayat 17. 


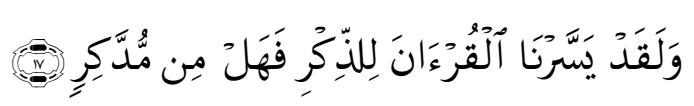

Artinya:"Dan Sesungguhnya Telah kami mudahkan Al-Quran untuk pelajaran, Maka Adakah orang yang mengambil pelajaran?"

Allah SWT mempermudah pemahaman Al-Qur`an antara lain dengan cara menurunkan sedikit demi sedikit, mengulang-ulangi uraiannya, memberikan serangkaian contoh dan perumpamaan menyangkut hal-hal yang Abstrak dengan sesuatu yang kasat indrawi melalui pemilihan bahasa yang paling kaya kosa katanya serta mudah di ucapkan dan dipahami, terasa indah oleh kalbu yang mendengarnya, lagi sesuai dengan nalar fitrah manusia agar tidak timbul kerancuan dalam memahami pesannya. ${ }^{4}$ Hal tersebut dapat diartikan bahwa membaca adalah suatu tindakan yang dapat menghasilkan sutu pemahaman dari suatu ilmu. Meskipun hal tersebut termasuk hal yang kasat di pandang mata atau abstrak.

Banyaknya lembaga pendidikan yang mendidik dalam belajar AlQur`an, maka lembaga pendidikan (sekolah) yang bercirikan agama (Islam) tanggung jawabnya lebih besar. Selain anak didik harus cakap dalam ilmu pengetahuan umum juga harus cakap ilmu agama pula.

Seiring berkembangnya zaman maka banyak metode-metode yang diciptakan untuk menunjang keberhasilan peserta didik dalam membaca Al-Qur`an dengan ciri-ciri tertentu demi mencapai keberhasilan dalam pembelajaran.

Lagu adalah karya sastra yang merupkan simbol dari ekspresi jiwa, perasaan, ide maupun gagasan yang mempunyai peranan penting bagi pendengarnya sebagai pemahaman, cara berhubungan, maupun cara penciptaan.

${ }^{4}$ M.Quraish shihab, Tafsir Al-Misbah, (Jakarta: Lentera Hati, 2009), hlm. 242-243. 
Sebagian besar anak kecil cenderung untuk menyukai lagu-lagu (nyanyian) dan suara yang merdu, terutama jika menggunakan kata-kata yang mudah dihafal. Lagu-lagu (nyanyian) tersebut dapat diperoleh secara lisan dan melalui kaset. Adapun tema dari lagu-lagu tersebut adalah tema-tema yang dapat membantu dan memudahkan peserta didik dalam memperoleh pengetahuan. Seperti kisah-kisah yang terdapat dalam AlQur`an seperti kisah-kisah tentang binatang dan para nabi, perbuatanperbuatan yang baik seperti jujur, membaca Al-Qur`an dan ketulusan. ${ }^{5}$

Pada penelitian ini, penulis mengangkat satu metode yang telah berkembang pada abad ini, yaitu metode Al-Husna. Metode Al-Husna merupakan metode balajar membaca Al-Qur`an yang menggunakan tiga langkah yang dapat mengantarkan peserta didik mampu membaca AlQur'an. ${ }^{6}$ Tiga langkah tersebut meliputi: penguasaan huruf hijaiyah dengan cara penskenan dan cerita pada metode Al-Husna, Penguasaan tanda baca yang sudah disesuaikan dengan mushaf usmani, serta dilakukan dengan sistem muroja'ah bersama. Metode Al-Husna ini juga di dukung dengan penerapan lagu dalam bacaan Al-Qur`an siswa akan lebih senang dalam proses pembelajaran dan gemar membaca Al- Qur`an sehingga berdampak pada hasil belajar siswa.

Dalam pembahasan ini, penulis akan memaparkan lebih lanjut tentang implementasi metode Al-Husna dalam pembelajaran baca tulis Al-Qur'an di SD Negeri Candirejo.

\section{B. Metode Penelitian}

${ }^{5}$ Syaikh Muhammad Said Mursi, Seni Mendidik Anak, (Jakarta: Arroya) hlm.144.

${ }^{6}$ Tri Wahyudi, Metode Al-Husna Mudah Membaca Al-Qur'an (Jetak Wonorejo: Maulana Media, 2013), hlm 7. 
Penelitian merupakan kegiatan untuk menemukan, mengembangkan atau mengkaji suatu pengetahuan. Oleh karena itu, penelitian harus di laksanakan secara sistematis dan rasional.

Jenis penelitian ini adalah kualitatif deskriptif, yaitu penelitiankualitatif yang berusaha menggambarkan dan menginterpretas $\mathrm{i}$ objek sesuai dengan apa adanya. ${ }^{7}$ Penelitian ini untuk memperoleh faktafakta atau peristiwa yang terjadi khususnya.

Pada penelitian kualitatif, data yang di kumpulkan umumnya berbentuk kata-kata. Kalaupun angka-angka sifatnya hanya sebagai penunjang, meliputi transkip, wawancara, catatan lapangan, foto-foto, dokumen pribadi, nota dan catatan lainnya. ${ }^{8}$ Metode ini digunakan untuk menganalisis data yang telah diperoleh tantang metode Al-Husna.

Metode ini berangkat dari fakta-fakta yang khusus, peristiwaperistiwa yang kongkrit, kemudian fakta-fakta dan peristiwa-peristiwa yang khusus kongkrit itu ditarik generalisasi-generalisasi yang mempunyai sifat umum. ${ }^{9}$ Dapat diartikan bahwa metode ini bermula dari fakta khusus kemudian ditarik menjadi kesimpulan yang bersifat umum.

Metode ini untuk menganalisa fakta yang ada di dalam lapangan kemudian ditarik kesimpulan menjadi kesimpulan umum sesuai dengan landasan teori yang ada. Metode ini digunakan untuk menganalisis data mengenai obyek penelitian yaitu SD Negeri Candirejo, serta untuk menyimpulkan data-data di lapangan yang berhubungan dengan pelaksanaan metode Al-Husna dalam pembelajaran membaca Al-Qur`an.

\footnotetext{
${ }^{7}$ Sukardi, Metodologi Penelitian Pendidikan kompetensi dan prakteknya, (Jakarta: Bumi Aksara, 2009), cet.7, hlm.157 hlm.61.

${ }^{8}$ Danim Sudarwan, Menjadi Peneliti Kualitatif, (Bandung: Pustaka Setia, 2002), ${ }^{9}$ Sutrisno Hadi, Metodologi Research, Jilid 1, (Yogyakarta: Andi Ofset, 1989), hlm 47.
} 


\section{Hasil Penelitian}

\section{Implementasi Metode Al-Husna Dalam Pembelajaran Baca Tulis} Al-Qur'an (BTA) di SD Negeri Candirejo

Pembelajaran Al-Husna dalam pembelajaran BTA dilaksanakan dengan 3 langkah, agar peserta didik mampu membaca Al-Qur'an dengan baik, cepat dan benar. Diantaranya adalah sebagai berikut:

a. Melalui proses scanning (fokus pada ciri huruf hijaiyyah).

Hal ini dimaksudkan agar talqin huruf hijaiiyyah dengan pelafalan yang fasih. Fokus penjelalasan pada cirri huruf tersebut adalah sebagai berikut:

b. Penguasaan sistem tanda baca.

$$
\text { خ ب ن }
$$

Metode Al-Husna mengambil acuan atau kutipan dari Mushaf Rasm Utsmani khususnya terbitan Al-Madinah An-Nabawiyyah dengan maksud memudahkan peserta didik dalam menguasai ilmu tajwid hanya dengan sistem tanda baca. Sistem tanda bacanya adalah sebagai berikut:

Tanwin/ Nun Sakinah dan Mim Sakinah

\begin{tabular}{|c|c|}
\hline $\begin{array}{l}\text { Sejajar maka dibaca jelas: } \\
\text { AN, IN, UN. }\end{array}$ & $\frac{\mathrm{o}^{\prime \prime}}{\bar{y}^{\prime}}$ \\
\hline $\begin{array}{l}\text { Bertumpuk dengan huruf } \\
\text { mim maka dibaca MIM: AM, } \\
\text { IM, UM. }\end{array}$ & $\frac{\dot{e}^{\prime}}{-}$ \\
\hline
\end{tabular}

c. Muroja'ah.

Sistem Al-Husna dalam muroja'ah adalah karena Al-Qur'an ini memiliki sifat yang unik atau dalam ungkapan lain Al-Qur'an memiliki sifat pencemburu yakni jika kita meninggalkannya dalam sehari, maka Al-Qur'an akan meninggalkan kita sepekan, jika kita 
tinggalkan dalam sepekan maka Al-Qur'an akan meninggalkan kita dalam sebulan. Begitu seterusnya.

Target yang digunakan oleh SD Negeri Candirejo untuk peserta didiknya yaitu:

1) Dapat membaca Al-Qur`an dengan lancar dengan baik dan benar.

2) mengerjakan shalat dengan baik dan benar, dengan indikasi: sadar akan kewajiban shalat, gemar melakukan jama'ah tepat waktu, mengerjakan shalat sesuai rakaatnya, hafal bacaan shalat dan di SD Negeri Candirejo ini ada kegiatan wajib sholat berjamaah yaitu sholat dzuha dan dzuhur, yang diatur waktu pelaksanaannya oleh lembaga tersebut.

3) Hafal surat-surat pendek dan aya-tayat pilihan serta doa seharihari; dan Berakhlakul karimah terhadap orang tua, guru dan temannya.

Kurikulum yang di gunakan dalam metode Al-Husna harus sesuai dengan panduan buku Al-Husna yang diterbitkan oleh lembaga Tim Al-Husna sehingga dalam pelaksanaannya pembelajaran membaca Al-Quran di SD Negeri Candirejo selalu berpedoman pada Al-Husna pusat.

\section{Materi Pengajaran Dalam Metode Al-Husna}

Materi pengajaran memegang peranan penting, tanpa adanya materi atau bahan pelajaran maka hasil dari proses pembelajaran (AlQur`an) tentunya tidak akan membawa hasil yang memuaskan.

Adapun materi pengajaran di SD Negeri Candirejo tidak menyangkut Al-Qur’an secara keseluruhan melainkan hanya sebagian saja. Yang telah ditetapkan dalam pedoman pendidikan Al-Qur`an 
pada lembaga tersebut. Adapun materi yang penulis maksudkan adalah sebagai berikut:

a. Materi Utama Dalam Metode Al-Husna

Materi utama yang diajarkan adalah jilid I sampai II. Dan setiap materi pembelajaran mempunyai tujuan masing-masing. Dalam kegiatan belajar mengajar di SD Negeri Candirejo, mempunyai tujuan pembelajaran yang berbeda-beda antara jilid III. Secara khusus akan dijelaskan tujuan pembelajaran membaca Al-Qur`an metode Al-Husna dari jilid I-IV.

1) Tujuan Jilid I

a) Santri mampu membaca terhadap penguasaan huruf hijaiyah dengan baik dan benar. Baik berharakat fathah berangkai, sambung maupun tidak dengan bacaan lancar satu ketukan.

b) Huruf hijaiyah asli.

c) Cara Pengajarannya yaitu:

(1) Penjelasan difokuskan kepada ciri huruf tersebut.

(2) Guru melafalkan huruf-huruf di dalam kotak ganda saja lalu diiikuti peserta didik.

(3) Peserta didik membaca seluruh latihan huruf di dalam kotak tunggal.

(4) Jika peserta didik lupa, maka guru hanya diperkenankan mengingatkan cirri huruf hijaiyah tersebut.

(5) Diperkenankan pindah ke halaman berikutnya jika tidak terjadi kesalahan sama sekali.

(6) Khusus setiap latihan kunci tidak cukup hanya membaca dengan benar, tetapi membacanya harus dengan lancar.

(7) Guru member catatan pada buku pemantau setiap selesai Kegiatan Belajar Mengajar (KBM). 
2) Tujuan Jilid II

a) Santri Santri lancar membaca kalimat berharakat fathah, kasrah, dan dhummah dengan benar.

b) Santri lancar membaca bacaan panjang dan pendek 2 harakat (mad).

c) Cara Pengajarannya yaitu:

(1) Mengenalkan huruf mad sebagai tanda panjang, baik ada rasm, maupun tidak ada rasm.

(2) Menjelaskan perbedaan pelafalan bacaan pendek dengan bacaan mad.

(3) Pelafalan huruf bertanda baca kasroh, posisi bibir dengan tersenyum.

(4) Pelafalan huruf bertanda baca dhommah, posisi bibir di monyongkan.

3) Tujuan Jilid III

a) Santri mampu membaca huruf-huruf sukun dengan sempurna tanpa ada kesalahan seperti; tawallud, dan saktah.

b) Santri tartil dan fasih membaca menggunakan irama rast.

c) Cara pengajarannya yaitu:

(1) Guru mentalqinkan cara melafalkan huruf yang sukun lalu diikuti peserta didik.

(2) Guru boleh member contoh dengan huruf latin sebagai alternative terakhir.

(3) Materi khusus bacaan sakinah ialah qolqolah serta bacaan ghunnah pada huruf bertasydid.

(4) Penjelasan pada hamzah washal, hanya terfokus pada huruf-huruf yang memiliki tanda baca.

4) Tujuan Jilid IV 
a) Santri menguasai praktek bacaan tanwin, nun sakinah dan mim sakinah, mad far'I dan waqaf.

b) Santri tartil dan fasih membaca menggunakan irama rast.

c) Cara mengajarnya yaitu:

(1) Guru menalqinkan materi bacaan tanwin dengan memperlihatkan bentuk-bentuk tanwin.

(2) Guru mentalqinkan materi bacaan nun sakinah dan mim sakinah dengan cara memperlihatkan tanda-tanda pada nun sakinah dan mim sakinah.

(3) Guru menalqinkan bacaan mad far'i dengan panjang 4/5/6 harokat.

(4) Guru menalqinkan materi bacaan yang di waqafkan, selesai materi waqaf, dilanjutkan dengan latihan membaca Al-Qur'an.

5) Materi Pendukung

a) Makhraj dan sifat huruf.

b) Ragam mad.

c) Ragam Ghunnah.

d) Idghom Shoghir.

e) Hamzah Washal.

f) Tafkhim dan Tarqiq.

g) Musykilatul Kalimat.

h) Hafalan surat-surat pendek.

b. Metode Pengajaran Dalam Metode Al-Husna

Sebagaimana yang telah disebutkan sebelumnya terkait dengan metode pengajaran, pada SD Negeri Candirejo menggunakan metode yang telah ditetapkan oleh Al-Husna, diantaranya yaitu dengan 3 pendekatan: 
1) Tartil

Tartil ialah mentajwidi huruf dan mengenal dimana harus waqaf. Kaidah ini menjadi konsekuensi logis setiap membaca Al-Qur'an terlebih bagi para pengajar Al-Qur'an. Karena tidak jarang peserta didik keliru dalam pelafalan Al-Qur'an disebabkan oleh pelafalan yang keliru pula dari pengajar AlQur'an.

2) Talqin-Talaqqi.

Talqin-Talaqqi merupakan kaidah yang tidak bisa ditinggalkan. Sebagaimana firman Allah dalam Q.S. AlQiyamah ayat 18.

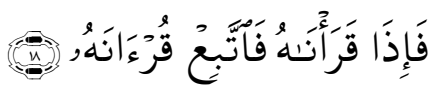

Artinya: "Apabila Kami telah selesai membacakannya Maka ikutilah bacaannya itu".

Dengan kualitas bacaan pengajar yang tartil maka Talqin-Talaqqi merupakan sarana terbaik agar tercapainya kualitas tartil yang optimal pada peserta didik.

3) Rasm Utsmani

Standar penulisan Al-Qur'an yang dikenal adalah dengan Rasm Utsmani terbitan Mujamma' Malik Fahd Madinah Nabawiyyah merupakan komponen terpenting berikutnya dalam proses KBM Al-Qur'an. Rasm tersebut memiliki banyak keistimewaan diantaranya adalah:

a) Dapat mengetahui hamzah washal, hamzah qath'i serta huruf alif.

b) Sesuai dengan kaidah mad ashli/ mad thabi'i.

c) Menguasai hukum nun mati atau tanwin dan mim mati dengan tanda baca. 
d) Mengetahui perbedaan system tanda baca mim mati dan nun mati atau tanwin pada terbitan Indonesia dan mushaf $\mathrm{Al}-$ Madinah An Nabawiyyah.

c. Pedoman Umum KBM Al-Qur'an dengan Metode Al-Husna

\begin{tabular}{|c|c|c|c|}
\hline $\begin{array}{c}\text { Program I } \\
\text { Mapel }\end{array}$ & $\begin{array}{c}\text { Tingkat } \\
\text { KBM }\end{array}$ & Peserta Didik & $\begin{array}{c}\text { Kompetensi } \\
\text { Pengajar }\end{array}$ \\
\hline \multirow[t]{3}{*}{$\begin{array}{l}\text { Baca Tulis } \\
\text { Al-Qur'an }\end{array}$} & Qur`an Dasar & $\begin{array}{l}\text { Belum Mampu } \\
\text { membaca Al- } \\
\text { Qur'an }\end{array}$ & $\begin{array}{l}\text { Tartil membaca } \\
\text { Al-Qur'an }\end{array}$ \\
\hline & Tilawah Juz i & $\begin{array}{l}\text { Membaca Al- } \\
\text { Qur`an } \\
\text { Terbata-bata }\end{array}$ & $\begin{array}{l}\text { Tartil membaca } \\
\text { Al-Qur'an }\end{array}$ \\
\hline & $\begin{array}{l}\text { Tahsin } \\
\text { Tilawah }\end{array}$ & $\begin{array}{l}\text { Lancar } \\
\text { Membaca Al- } \\
\text { Qur`an Namun } \\
\text { Masih Sering } \\
\text { Melakukan } \\
\text { Kesalahan } \\
\text { Khofy } \\
\end{array}$ & $\begin{array}{l}\text { Tartil membaca } \\
\text { Al-Qur'an dan } \\
\text { Menguasai } \\
\text { Teori }\end{array}$ \\
\hline \multirow[t]{2}{*}{$\begin{array}{l}\text { Program } \\
\text { Tahfizh Al- } \\
\text { Qur'an }\end{array}$} & $\begin{array}{l}\text { Talqin } \\
\text { Tahfizh }\end{array}$ & $\begin{array}{l}\text { Belum Tartil } \\
\text { membaca } \\
\text { Qur'an }\end{array}$ & $\begin{array}{l}\text { Hafal Al- } \\
\text { Qur'an minimal } \\
\text { juz } 30\end{array}$ \\
\hline & $\begin{array}{l}\text { Talaqqi } \\
\text { Syamil }\end{array}$ & $\begin{array}{l}\text { Belum Tartil } \\
\text { membaca } \\
\begin{array}{l}\text { Our'an } \\
\text { Our' }\end{array}\end{array}$ & $\begin{array}{l}\text { Hafal Al- } \\
\text { Qur'an minimal } \\
\text { juz } 30\end{array}$ \\
\hline
\end{tabular}

d. Standar Umum Operasional Pengajaran (SOP) Metode Al-Husna

\begin{tabular}{|c|c|c|}
\hline SOP & Skenario Kegiatan & $\begin{array}{c}\text { Dokumen } \\
\text { Terkait }\end{array}$ \\
\hline $\begin{array}{c}\text { TES } \\
\text { KEMAMPUAN }\end{array}$ & $\begin{array}{l}\text { Klasifikasi tingkat } \\
\text { peserta didik menurut } \\
\text { kemampuan } \\
\text { membaca Al-Qur`an: } \\
\text { 1. Bagian Akedemik } \\
\text { menyiapkan } \\
\text { perangkat kegiatan. } \\
\text { 2. Peserta didik mengisi } \\
\text { Form Biodata Peserta } \\
\text { Didik }\end{array}$ & $\begin{array}{l}\text { 1. Biodata Calon } \\
\text { Peserta Didik } \\
\text { 2. Database Calon } \\
\text { Peserta Didik } \\
\text { 3. Soal Tes } \\
\text { Kemampuan } \\
\text { Praktek Tes } \\
\text { 4. Soal } \\
\text { Kemampuan } \\
\text { Teori }\end{array}$ \\
\hline
\end{tabular}




\begin{tabular}{|c|c|c|}
\hline & $\begin{array}{lr}\text { 3. Tim Penguji } & \text { Mengisi } \\
\text { biodata pada } & \text { Form } \\
\text { Hasil } & \text { Tes } \\
\text { Kemampuan } & \\
\text { 4. Peserta } & \text { didik } \\
\text { mengerjakan } & \text { soal tes } \\
\text { kemapuan } & \\
\text { 5. Tim Penguji } & \text { menilai } \\
\text { kemampuan peserta } \\
\text { didik dengan mengisi } \\
\text { Form Hasil Tes } \\
\text { Kemampuan rr } \\
\text { 6. Tim penguji meng- } \\
\text { input Form Hasil Tes } \\
\text { Kemampuan pada } \\
\text { Alat Uji Kemampuan } \\
\text { 7. Tim penguji mengisi } \\
\text { Form Database hasil } \\
\text { tes kemampuan } \\
\text { 8. Bagian Akademik } \\
\text { merekap hasil tes } \\
\text { kemampuan pada } \\
\text { Rapor }\end{array}$ & $\begin{array}{l}\text { 5. Hasil Tes } \\
\text { Kemampuan } \\
\text { 6. Alat Uji } \\
\text { Kemampuan } \\
\text { 7. Rapor Evaluasi } \\
\text { KBM }\end{array}$ \\
\hline KBM & $\begin{array}{l}\text { Baca Tulis Al Qur`an: } \\
\text { 1. Bagian Akademik } \\
\text { menyiapkan } \\
\text { perangkat KBM } \\
\text { 2. Talqin-Talaqqi } \\
\text { materi oleh pengajar } \\
\text { 3. Pengajar mengisi } \\
\text { data perkembangan } \\
\text { pada form Lembar } \\
\text { Pemantau } \\
\text { Tahfizh Al Qur`an: } \\
\text { 1. Talqin hafalan bagi } \\
\text { peserta didik yang } \\
\text { belum } \\
\text { tartil membaca Al } \\
\text { Qur`an. } \\
\text { 2. Talaqqi Syamil } 30 \\
\text { juz }\end{array}$ & $\begin{array}{l}\text { 1. Buku Metode } \\
\text { Al Husna } \\
\text { 2. Alat Peraga } \\
\text { 3. Mushaf Juzi i } \\
\text { 4. Mushaf Al } \\
\text { Qur`an } \\
\text { 5. Silabus dan } \\
\text { RPP } \\
\text { 6. Cara Mengajar } \\
\text { Metode Al } \\
\text { Husna } \\
\text { 7. Lembar } \\
\text { Pemantau }\end{array}$ \\
\hline
\end{tabular}




\begin{tabular}{|c|c|c|}
\hline $\begin{array}{l}\text { EVALUASI } \\
\text { KBM }\end{array}$ & $\begin{array}{l}\text { Evaluasi Kegiatan } \\
\text { Belajar Mengajar: } \\
\text { 1. Bagian Akademik } \\
\text { menyiapkan } \\
\text { perangkat Evaluasi } \\
\text { KBM } \\
\text { 2. Peserta didik } \\
\text { mengerjakan Soal } \\
\text { Evaluasi KBM } \\
\text { 3. Tim Penguji menilai } \\
\text { kemampuan peserta } \\
\text { didik dengan mengisi } \\
\text { Form Hasil Evaluasi } \\
\text { KBM penguji meng- } \\
\text { 4. Tim penil } \\
\text { input Form Hasil } \\
\text { Evaluasi pada Alat } \\
\text { Uji Kemampuan } \\
\text { 5. Tim penguji mengisi } \\
\text { Form Database Hasil } \\
\text { Evaluasi KBM } \\
\text { 6. Bagian Akademik } \\
\text { merekap hasil tes } \\
\text { kemampuan pada } \\
\text { Rapor }\end{array}$ & $\begin{array}{l}\text { 1. Soal Evaluasi } \\
\text { KBM } \\
\text { 2. Hasil Evaluasi } \\
\text { 3. Alat Uji } \\
\text { Kemampuan } \\
\text { 4. Database Hasil } \\
\text { Evaluasi KBM } \\
\text { 5. Rapor }\end{array}$ \\
\hline SERTIFIKAT & 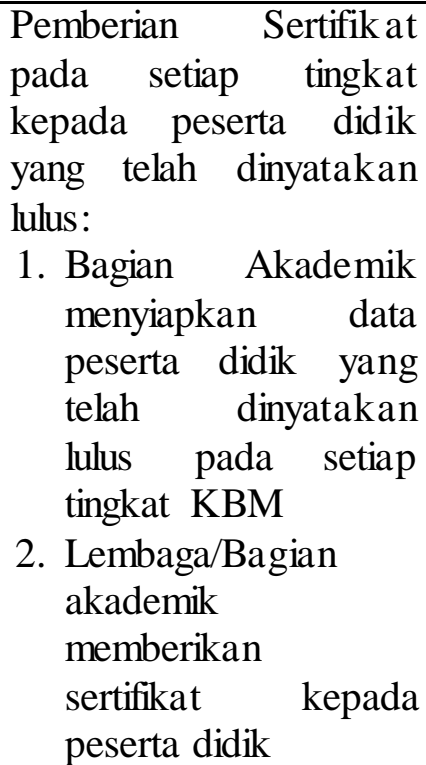 & $\begin{array}{l}\text { 1. Database Hasil } \\
\text { Evaluasi KBM } \\
\text { 2. Sertifikat } \\
\text { Kelulusan }\end{array}$ \\
\hline
\end{tabular}




\section{PEMBAHASAN}

\section{Analisis Pelaksanaan Metode Al-Husna Dalam Pembelajaran Baca Tulis Al-Qur'an (BTA) di SD Negeri Candirejo}

Metode scanning yang diterapkan bagi siswa SD Negeri Candirejo, guru terlebih dahulu menjelaskan tujuan materi yang akan disampaikan. Penjelasan tujuan materi ini agar siswa mengetahui kegiatannya dalam belajar. Tujuan tersebut juga dapat membangkitkan motivasi belajar siswa.

Guru sangat memahami kondisi siswa, oleh karena itu materi disampaikan dengan jelas, pelan, dan penjelasan guru senantiasa diulang-ulang agar siswa lebih memahami maksud yang disampaikan guru. Metode ini mengandalkan kepiawaian guru dalam berkomunikasi dan mengondisikan siswa agar tetap fokus terhadap pelajaran.

Apabila terdapat poin penting dari materi, maka materi tersebut disampaikan dengan cara mengulang kalimat dan menanyakan kepada siswa apakah sudah paham materi yang disampaikan guru.

Penerapan metode scanning bagi siswa diawali dengan guru menyampaikan materi dengan jelas, pelan dan diulang-ulang agar siswa lebih paham materi yang disampaikan. Gurupun juga memberi kesempatan siswa untuk menanyakan hal yang belum mereka ketahui. Media yang digunakan guru adalah papan tulis dan alat tulis.

Dalam menggunakan metode scanning, pendidik tilawati menerapkan langkah-langkah berikut ini:

a. Dalam menerangkan pelajaran Guru Tilawati menggunakan katakata yang sederhana, jelas, dan mudah dipahami oleh para siswa. 
b. menggunakan alat visualisasi, seperti penggunaan papan tulis atau media lainnya yang tersedia untuk menjelaskan pokok bahasan yang disampaikan.

c. Merinci bahan yang disampaikan, dengan menghubungkan materi dengan contoh-contoh yang konkrit.

Metode penguasaan system tanda baca dilaksanakan ketika anak selesai dalam pembelajaran, hal ini berguna untuk peserta didik sendiri untuk melatih kemandirian.

Manfaat pemberian tugas yang diberikan kepada siswa antara lain:

a. Siswa belajar mengambil inisiatif sendiri dalam segala tugas yang diberikan.

b. Dapat mempertebal rasa tanggung jawab, karena tugas yang dikerjakan dipertanggungjawabkan dihadapan guru.

c. Dapat memperdalam pengertian dan kecakapan siswa.

Hal-hal yang hendaknya dilakukan guru agar pemberian tugas yang diberikan dapat bermanfaat untuk siswa dan melatih siswa bertanggung jawab antara lain:

a. Membimbing Siswa yang mengalami kegagalan harus dibimbing.

b. Menghargai setiap tugas yang dikerjakan murid.

c. Memberikan dorongan bagi siswa untuk melaksanakan tugas dengan baik.

Metode tanya jawab belum dilaksanakan oleh pendidik di SD Negeri Candirejo. Diantara metode muroja'ah ini adalah:

a. Menyimpulkan pelajaran yang telah lalu. Setelah guru menguraikan suatu persoalan, kemudian guru mengajukan suatu pertanyaan. 
b. Melanjutkan pelajaran yang telah lalu. Dengan mengulang pelajaran yang sudah diberikan dalam bentuk pertanyaan, guru akan dapat menarik perhatian kepada pelajaran baru.

c. Memimpin pengamatan atau pemikiran murid. Ketika murid menghadapi suatu persoalan maka pemikiran murid dapat dibimbing dengan mengajukan pertanyaan. Saat murid tidak memperhatikan guru, diberi pertanyaan mendadak agar perhatian murid kembali kepada guru dan mendengarkan penjelasan guru.

d. Menyelingi pembicaraan untuk merangsang perhatian murid dalam belajar sehingga dengan jalan demikian dapat meningkatkan semangat murid.

\section{Analisis Materi Utama Dalam Metode Al-Husna}

Penerapan metode Al-Husna yang terdiri dari tiga pendekatan yaitu tartil, talqin-talaqqi dan rasm utsmani di SD Negeri Candirejo dalam prakteknya tidak hanya menggunakan tiga metode tersebut, yakni tergantung situasi dan kondisi anak dalam kelas.

Adapun materi pengajaran di SD Negeri Candirejo tidak menyangkut $\mathrm{Al}-\mathrm{Qur}$ an secara keseluruhan melainkan hanya sebagian saja. Yang telah ditetapkan dalam pedoman pendidikan Al-Qur`an pada lembaga tersebut.

a. Materi Utama

Materi Utama yang diajarkan adalah jilid I sampai jilid IV

b. Materi Pendukung

1) Makhraj dan sifat huruf.

2) Ragam mad.

3) Ragam Ghunnah.

4) Idghom Shoghir.

5) Hamzah Washal. 
6) Tafkhim dan Tarqiq.

7) Musykilatul Kalimat.

8) Hafalan surat-surat pendek.

\section{Analisis Pedoman Umum KBM Al-Qur'an dengan Metode Al-}

\section{Husna}

Pembelajaran merupakan sebuah proses membelajarkan siswa dalam membaca Al-Qur'an dimana dalam proses pembelajaran tersebut menghasilkan perubahan yang bersifat permanen dan dapat ditunjukkan dengan perubahan pengetahuan pemahaman sikap dan tingkah laku serta keterampilan maupun kebiasaan-kebiasaan serta perubahan aspek lain.

Adapun dalam proses pembelajaran membaca Al-Qur`an, SD Negeri Candirejo menggunakan pendekatan Tartil, Talqin-Talaqqi dan Rasm Utsmani. Dan pada proses pembelajarannya tersebut diharapkan guru dapat mengajarkan pokok pelajaran ditiap-tiap halaman tilawati maupun menyampaikan materi yang sulit secara berulang-ulang.

Proses pembelajaran diharapkan guru dapat mengajarkan pokok pelajaran yang ada di setiap halaman Tilawati, maupun menyampaikan materi yang sulit secara berulang-ulang. Demikian siswa yang kurang lancar dapat mengikutinya dengan baik. Selain itu dalam proses pembelajarannya dalam satu kelas terdiri dari kelompok-kelompok, yang setiap kelompoknya terdiri dari guru tetap. Sehingga anak yang di didik dapat konsentrasi melaksanakan pelajaran, dan gurupun dapat mendidik anak didiknya secara maksimal.

Untuk materi pendukung hafalan surat-surat pendek yang targetnya adalah pada juz 30, panduan pembelajarannya masih dalam tahap pengembangan oleh tim Al-Husna. Karena dalam praktiknya 
masih terpacu pada Baca Tulis Al-Qur'an (BTA), dalam artian masih pada target tartil membaca Al-Qur'an.

\section{Analisis Standar Umum Operasional Pengajaran (SOP) Metode}

\section{Al-Husna}

Proses pembelajaran diharapkan guru dapat mengajarkan pokok pelajaran yang ada di setiap halaman pada metode Al-Husna, maupun menyampaikan materi yang sulit secara berulang-ulang. Demikian siswa yang kurang lancar dapat mengikutinya dengan baik. Selain itu dalam proses pembelajarannya dalam satu kelas terdiri dari kelompokkelompok, yang setiap kelompoknya terdiri dari guru tetap. Sehingga anak yang di didik dapat konsentrasi melaksanakan pelajaran, dan gurupun dapat mendidik anak didiknya secara maksimal.

Pelaksanaan evaluasi pembelajaran Al-Qur`an metode Al-Husna tiga bentuk, yaitu pre tes, tes harian, dan tes kenaikan jilid yang dilaksanakan setiap 3 bulan 1x. dalam evaluasi kenaikan jilid peserta didk dibebani minimal 10 halaman untuk dibaca. Dan ketentuan halaman diserahkan penuh kepada penguji masing-masing peserta didik.

Pelaksanaan evaluasi untuk kenaikan halaman langsung dilaksanakan ketika saat proses belajar mengajar berlangsung, yaitu seorang pendidik langsung mengamati kemampuan peserta didiknya, karena dalam proses belajar mengajar pada metode baca simak kemampuan siswa dalam membaca, memnerapkan lagu rast dapat dinilai langsung oleh pendidik.

Guru menggunakan media peraga untuk mengajari siswa membaca. Teknis pengajarannya dengan memperhatikan peraga yang berisi materi bacaan Al-Husna, sehingga pandangan siswa terpusat pada bacaan yang ada di dalam peraga tersebut. Pada penerapannya 
Jurnal Pendidikan Agama Islam Universitas Wahid Hasyim Semarang

yang dilakukan oleh pendidik dalam tahap awal adalah guru membaca siswa menirukan, kemudian guru membaca siswa menirukan, dan langkah ketiga membaca bersama antara guru dan siswa.

\section{E. KESIMPULAN}

Berdasarkan hasil penelitian yang lakukan di SD Negeri Candirejo, dapat disimpulkan sebagai berikut:

1. Penerapann metode Al-Husna di SD Negeri Candirejo, mempunyai ciri khas tersendiri yaitu dengan pendekatan Klasikal dan Individual. Pendekatan metode Al-Husna dilaksanakan dengan 3 tehnik yaitu:

a. Tehnik 1 (tartil yaitu Tartil ialah mentajwidi huruf dan mengenal dimana harus waqaf).

b. Tehnik 2 (guru membaca siswa menirukan).

c. Tehnik 3 guru dan siswa sama-sama membaca dengan kaidah rasm utsmani.

2. Evaluasi dalam tilawati ini dilakukan setiap 3 bulan sekali untuk kenaikan jilid. Sedangkan untuk kenaikan halaman setiap di akhir pertemuan sebelim pulang, dengan ketentuan dari pendidik, dan sesuai pedoman pelaksanaan imtihan. 
Jurnal Pendidikan Agama Islam Universitas Wahid Hasyim Semarang

\section{DAFTAR PUSTAKA}

Al-Maraghi, Ahmad Musthafa. 1993. Tafsir Al-Maraghi ,juz XV. Semarang: Karya Thoha Putra.

Arikunto, Suharsimi. 2006. Prosedur Penelitian Suatu Pendekatan Praktek. Jakarta: Rineka Cipta.

Fathoni, Abdurrahmat. 2006. Metodologi Penelitian \& Teknik Penulisan Skripsi. Jakarta: Rineka cipta.

Hadi, Sutrisno. 1989. Metodologi Research, Jilid 1. Yogyakarta: Andi Ofset.

Khon, Abdul Majid. 2008. Praktikum Qiraat Keanehan Bacaan Al-Qur`An Qiraat Ashim Dari Hafash. Jakarta: sinar grafika offset.

Mursi, Syaikh Muhammad Said. Seni Mendidik Anak. Jakarta: Arroya.

Nazir, Moh. 2009. Metode Penelitian. Bandung: Ghalia Indonesia.

Shihab, M. Quraish. 2009. Tafsir Al-Misbah. Jakarta: Lentera Hati.

Sudarwan, Danim. 2002. Menjadi Peneliti Kualitatif. Bandung: Pustaka Setia.

Sukardi. 2009. Metodologi Penelitian Pendidikan kompetensidan prakteknya. Jakarta: Bumi Aksara.

Syarifuddin, Ahmad. 2005. Mendidik Anak Membaca, Menulis, Dan Mencintai Al-Qur`an. Jakarta: Gema Insani.

Wahyudi, Tri. 2013. Metode Al-Husna Mudah Membaca Al-Qur'an. Jetak Wonorejo: Maulana Media. 